\title{
七彩丹霞资源在中小学美术课程中的应用研究
}

杨丽芸

甘肃省张掖市甘州区思源实验学校

DOI:10.32629/jief.v2i7.1909

[摘要] 随着新课程的实施, 我们更加深刻的认识到如何让学生体会生活, 寻找生活中的美, 创造生活中的艺术, 是现代美术教育教学的重 点。而利用身边的旅游资源开发校美术课程, 可以使教学的内容得到补充与延伸。如何把旅游资源应用到美术课程上来, 提高学生环境保护 意识, 也是我们美术老师应尽的责任。将学生带进巧用旅游资源创造美好世界的新境地, 不断地引导学生去发现、认识、体验、不断提升学 生的审美情趣。

[关键词] 中小学美术; 课程; 应用研究

中图分类号：G633.955 文献标识码：A

在本研究中, 七彩丹霞美术课程资源的开发从学生的生活出发, 基 于中小学美术教材关于装饰设计、关注身边的美术遗存、传统民居的艺 术魅力等课程, 开发以认识七彩丹霞的特殊地貌, 利用媒材动手制作七 彩丹霞特色的美术课程。

通过课程开发, 师生共同探究, 帮助学生了解本地地貌, 通过对七 彩丹霞文化美术课程的学习, 学生汲取七彩丹霞的精髓, 传承七彩丹霞 的文化, 滋养和陶冶人文情操。从美术教学来看, 为中小阶段美术新课 改从传统技巧学习上升为学习美术文化, 追求人文性质的美术课堂提供 不一样的想法。

\section{1 简析本地美术课程资源在中小学中的开发和利用存在问题}

在中小学的美术课堂创新改革中, 经过大量的实践和调查, 我们不 难发现当地的人文地理文化等资源能等对于提升小学生对美术课程的热 爱和积极性有很大的助益, 这很大程度上促进了中小学书美术教育的发 展。

我们的课程资源分为知识资源, 物质资源, 文化资源和自然资源等。 要简析本地美术课程资源在中小学应用中的开发和利用的存在问题, 首 先了解甘肃省地域文化特点。甘肃省的地域文化历史悠久而且非常丰富。 它位于我国中东部腹地通往西北地区的走廊过渡地带, 也是闻名于世的 丝绸之路所经的交通枢纽。从文化艺术上来说, 这里有我们耳熟能详的, 彩陶, 壁画, 石窟摩崖石刻等极具民族代表性的艺术宝藏。

而在我们的小学美术课堂创新改革中, 甘肃省本地的中小学美术教 育课的课程资源利用方面还是存在一定问题。通过问卷调查我们分别了 解本地美术课程资源开发与利用现状与问题。首先, 是因为本地的经济 状况, 地域等诸多现实原因, 基层教育工作者对于本地的地域文化资源
运用较少, 或是直接没有运用到。据调查了解到很多在中小学的很多美 术课堂中, 大多遵循传统的教育美术教育方式, 根据教材, 或者说只是 在身边周围寻找课程资源。在调查中, 也发现不少中小学的美术课程资 源, 存在片面性, 单向性等, 因为教育工作者的审美不一, 并没有发现 当地地域文化资源其中富含的深刻价值, 对其选择利用性非常的片面。 例如选择介绍当地有特色的景点文化遗产时, 在课堂中也只是蜻蜓点水 般, 具体内容提到较少。

\section{2 开发以七彩丹霞为核心的美术课程资源}

本课题以开发七彩丹霞为核心的美术课程资源。甘肃张掖七彩丹霞 地貌是当地非常著名的一个 $5 \mathrm{~A}$ 级景区。是大自然留给临泽人民的一份宝 贵自然遗产, 其占地面积薄庞大, 气势磅礴, 形态丰富, 造型奇特, 色彩 艳丽。其绵延数十公里, 宛如大地之母披上一件绝美的五彩衣裳。七彩 丹霞从具象的形态美, 色彩美, 到抽象的民俗历史文化沉淀等, 都非常 适合作为课程资源运用到美术教育中。并且七彩丹霞地貌本身就是当地 特色, 运用到教学中, 即会变成教学的特色。教师从不同的方面角度来 引导学生发现七彩丹霞的美, 并学会将其美运用到绘画作品中。不仅如 此, 七彩丹霞的美, 本身就是来自于自然, 磅礴壮丽, 震撼人心的一种 美, 是比传统教育中向学生展示学习任何一种书面教材内容无可比拟的。 它作为课程资源晕到我们的教学中, 不仅使我们美术教学锦上添花, 最 重要的一个方面是培养学生对当地文化特色的理解程度, 推进学生们对 于自己的家乡文化的理解与热爱。提高其对于艺术的认知能力。更为当 地的美术教育发展迈出一大步。

在充分了解国内外本地美术课程资源开发与利用的研究现状、本地 美术课程资源开发的方法、本地美术课程资源开发的优缺点后, 我们为研 
究开发以七彩丹霞为核心的美术课程资源寻找参考, 并且结合教学实际 和调查结果, 提出了七彩丹霞为核心的美术课程的设计。

\section{3 七彩丹霞为核心的美术课程的设计}

七彩丹霞美术课程资源的开发是从学生的生活出发, 基于中小学美 术教材关于装饰设计、关注身边的美术遗存、传统民居的艺术魅力等课 程, 开发以认识七彩丹霞的特殊地貌, 利用媒材动手制作七彩丹霞特色 的美术课程。我们的目标在于, 通过课程开发, 师生共同探究, 帮助学 生了解本地地貌。再通过对七彩丹霞文化美术课程的学习, 学生汲取七 彩丹霞的精髓, 传承七彩丹霞的文化, 滋养和陶冶人文情操。从美术教 学来看, 为中小阶段美术新课改从传统技巧学习上升为学习美术文化, 追求人文性质的美术课堂提供不一样的想法。

\section{4 基于此，笔者做出了如下美术课程设计:}

4.1 利用多种途径及方法引导学生发现七彩丹霞之美

美术课程标准中对美术课程资源的 “开发与利用” 条例作出了进一 步的完善。各校应配齐美术教学设备与器材, 配置美术专用教室, 并提供 储藏教具、工具、材料的场所以及展示学生美术作品的场所。有条件的 学校应配置可供美术课使用的多媒体教学设备。学校的图书馆应配备美 术书籍和其他美术资源, 包括教师参考书、学生参考书、美术杂志、美术 教育杂志、幻灯片和光盘等, 供教师备课及上课, 学生收集、查阅资料以 及自学或合作学习时使用。广泛利用校外的各种课程资源, 包括美术馆、 图书馆、公共博物馆及私人博物馆、当地文物资源、艺术家工作室和艺 术作坊等。

而教师也应该特别注重广泛利用校内的各种课程资源, 为教育与教 学服务。如在教育条件, 资源允许的情况下, 教师应该积极开发信息化 课程资源, 充分利用网络获得最新的七彩丹霞为核心的教育资源。向学 生们传输表达丹霞地貌之美时, 广泛利用音频, 纪录片, 图片展览, PPT 形式等多个渠道, 引领学生们充分了解到丹霞地貌是什么, 其魅力之处 在哪。有条件的情况下, 还可带学生到实地参观, 因为身临其境之美, 要优于其他任何一种形式的转述。如果没有这种条件, 教师更应该做到 更丰富形式的给学生。全面多方位地展现七彩丹霞之美。

4.2 激发学生主动积极参与特色资源材料的收集

在美术课程设计中, 笔者做到创新的一点是, 将对学生审美情趣的 教育延伸到课堂之外, 即是我们不只在课堂中向学生们讲述美是怎么样
子的? 我们应该如何去感受美? 而是积极鼓励学生们自主积极地去探索 和发现生活周边的美。采取走出去的形式, 例如鼓励学生, 利用假期的 时间, 或利用走亲访友的机会, 去收集一些关于丹霞美景的图片, 让学 生增长见识, 深入群众, 了解实际, 着重了解百姓的人文景观、人文素 养、人文环境, 这是学生接触家乡的过程, 也是进行爱家乡教育的最佳 时机。

4.3 开办七彩丹霞绘画展对审美情趣的再提升

在充分和同学生讲解七彩丹霞的文化, 展示七彩丹霞艺术审美价值, 使学生能够在老师的引导下领悟到具有的形态美, 色彩美后, 最终还让 学生走出课堂, 实际考察去了解七彩丹霞文化, 提升学生对当地人文风 俗的了解层度。我们更主要的是使学生学有所得, 而开办以七彩丹霞为 主题的画展就是最好的一种方式。鼓励学生以自己的视角, 理解来表现 美, 创造美。成品出现时, 老师更应该给予学生正面积极的鼓励。让他 们明白艺术是来源于我们的生活。并且真真正正的感受到生活融入到生 活, 获得美的体验, 形成自然真实的审美情趣。

\section{5 总结}

七彩丹霞资源在中小学美术课程中的应用研究中, 笔者始终相信, 向学生介绍七彩丹霞自然风光的同时, 再激发他们自主积极的探索身边 的特色资源材料的收集, 再到将七彩丹霞融入到自己的美术画作中, 使 其感受到其艺术来源于生活, 让学生为本地有秀美的自然景色而感到自 豪。引导他们热爱祖国、热爱大自然、珍惜美好的环境, 陶冶健康的审 美情趣, 提高审美能力。唤起学生表现故乡美景的欲望。

\section{[基金项目]}

本课题为甘肃省教育科学 “十三五” 规划 2019 年度一般棵题, 课题 立项号：GS[2019]GHB0790。

\section{[参考文献]}

[1]孙少炜.互动式教学在小学美术教学中的实践研究 [J].当代家庭 教育,2020(23):118-119.

[2]刘浦.小学美术课堂对学生综合性学习的培养分析 [J]. 读写 算,2020(22):176

[3]万昌巧. 小学美术教学中如何培养学生的创新能力 [N]. 黔西南日 报, 2020-08-09(004). 